SSCN T

Journal of Sustainable Construction

Materials and Technologies

\title{
Journal of Sustainable Construction Materials and Technologies
}

www.eds.yildiz.edu.tr/jscmt

\section{Economic and Technological Evaluation of Transportation System, New Trends}

\author{
Taha $\operatorname{Vardar}^{1 *}$, Mehmet Fatih Altan ${ }^{1, a}$, Sepanta Naimi ${ }^{1, b}$ \\ ${ }^{1}$ Department of Civil Engineering, Istanbul Aydin University, Istanbul, Turkey \\ amehmetaltan@aydin.edu.tr, bsepanta.naimi@gmail.com
}

Received October 10, 2016; accepted December 12, 2016

\begin{abstract}
Objective of the study is revealing developments year by year that has the faces of economical, technical, social, political and trying to clarify the relationship between different disciplines and transportation. On this context, with the affect of extension on informatics and technology on last decades, the type of development trends of transportation system is discussed within the frame of today's necessities. On this context, it is known that transportation has a mutual and integrated relationship with urbanization and it has understood that transportation is impulsion of common civilization level of humanity.
\end{abstract}

In this content, development period and continuing investments of high speed railway that is a part of future perspective which is executed on the frame of development trends with economical and technological context of transportation system are evaluated detailed too.

Keywords: Balanced Modal Distribution, High Speed Railways, Sustainability, Transportation Infrastructure, Transportation System

\section{Introduction}

The economic possibilities provided in the cities cause the development of the urban economy and hence the income per capita to increase. This increase can be defined as the increase in the level of wealth. As a result of this increase, the mobility in urban space, that is, the transportation also develops. On the other hand, this mobility in the urban space also causes concerns about the ecological environment and sustainable spatial development.

All of these developments, along with new urbanism and smart growth, have brought together the search for new plans regarding urban land planning and reducing the need for excessive vehicle use.

There is a significant link between urban development and transportation in the national and regional scale. Main transport networks, rail networks, airports and ports all have significant impacts on the local economy. In urban settlements, this effect is accelerating and even determining the socio-economic and cultural developments. For this reason, experts from many different disciplines, such as urban planners, economists, strategists, city politicians, etc., need to be in a position to be the decision makers that will shape the situation regarding the increase and differentiation of transportation needs.

It can be said that railway transportation is more effective in high density areas of the city. As a result of the developments that occur in the urban areas with the city leaping towards the suburbs, it is difficult for urban residents to travel to and from the city center or other areas, and rail transport and other public transport arrangements can be a solution to this problem. Especially in the cases where the highway is inadequate, the inner-city railway lines are in the foreground due to their uninterrupted transportation features.

* Corresponding author. Tel.: +90 5301083283 .

E-mail address: vardartaha@hotmail.com .

https://doi.org/10.29187/jscmt.2018.11 
At local level, the emergence of high-speed train networks provided fast and efficient inter-city services, especially in France (1981, TGV, up to $300 \mathrm{~km} / \mathrm{h}$ ) and Japan (1964; Shinkansen, up to $275 \mathrm{~km} / \mathrm{h}$ ).

Industrial companies engaged in transportation equipment, such as automobile manufacturers, have become main actors of the global economy. Although not an international type of transportation, the spread of automobiles has increased the global trade of spare parts, raw materials and fuel (mainly oil). Automobile production, which is mainly concentrated in countries like the US, Japan and Germany, has become a global industry with few players participating. Along with oil producers, automobile producers have followed strategies aimed at spreading the automobile as the main type of individual transport. Although this ensured increase in mobility, it has also led to agglomeration and energy waste. As the 21 st century starts, automobiles are responsible for $80 \%$ of total petroleum consumption in developed countries [1].

Above all; there is considerable diversity in terms of railway infrastructure, trains, average and maximum speeds, and level of service. Especially, in a given technology, the difference between the maximum speed achieved in the test drive or in private driving, and the average speed in public transportation services should be clearly drawn. While service requirements bring significant constraints on railway technology, competitive features are not only speed, but also capacity, frequency, safety and comfort. These characteristics are attractive especially for developing economies with good transportation conditions that require heavy population, traffic jam, clustered urban network deployment. These conditions can be increased depending on the inadequacy of the land and expensiveness or the comparative cost calculation between alternative modes (primarily airway and highway). Under these conditions; in general, for distances over $800 \mathrm{~km}$ and over 4 hours travel; HSR is more competitive than airway or highway.

The following table shows the time gains emerged with the high-speed railway construction and development in the relevant regions.

Table 1. Time Gains provided by High Speed Railways [2]

\begin{tabular}{|c|c|c|c|c|c|c|c|}
\hline Line & $\begin{array}{l}\text { Before } \\
\text { HSR(min.) }\end{array}$ & $\begin{array}{l}\text { First } \\
\text { HSR } \\
\text { (min) }\end{array}$ & $\begin{array}{l}\text { Improved } \\
\text { HSR (min) }\end{array}$ & $\begin{array}{l}\text { First } \\
\text { Gain } \\
\text { (min) }\end{array}$ & $\%$ & $\begin{array}{l}\text { Second } \\
\text { Gain } \\
\text { (min) }\end{array}$ & $\%$ \\
\hline $\begin{array}{l}\text { Tokyo- } \\
\text { Osaka } \\
\text { Paris- }\end{array}$ & 420 & 240 & 145 & 180 & 43 & 275 & 65 \\
\hline $\begin{array}{l}\text { Lyon } \\
\text { Madrid- }\end{array}$ & 227 & 160 & 115 & 67 & 30 & 112 & 49 \\
\hline $\begin{array}{l}\text { Seville } \\
\text { London- }\end{array}$ & 390 & 152 & 140 & 238 & 61 & 250 & 64 \\
\hline
\end{tabular}

As shown in Table 1, there is a $30 \%$ to $61 \%$ improvement in travel time with the construction of the first high-speed railway line in a region. The cities are the ones in developed countries and nowadays, they have significant high-speed line kilometers. As a second step on the high-speed railway lines in these cities, an improvement was made after a certain period of time, which resulted in a partial improvement in travel time and a total improvement of up to 68\% compared to the time when there were not any high speed railways.

\section{Transportation Policies in the European Union}

In Europe, the EU has encouraged HSR Production from the 1990s on in the continent. This incentive emerged in 1992 as the Trans-European Networks (TEN), but over time it has turned into one of the industry's main tools. Along with that; until the early 1990s, investment support was still below acceptable levels. However, beyond national acceptance, route plannings brought about the PBKAL Line by linking Paris, Brussels, Cologne and Amsterdam to London with the Canal Tunnel. While the driving force in HSR in Europe was clearly France, this country was included in the HSR with the name of TGV (HSR) by opening the Paris-Lyon line in 1981. France first introduced the HSR operation with improvements on the existing conventional line. As of 1983, the $430 \mathrm{~km}$ distance between these two cities was a two hour journey.

Following that, both Japan and France focused on linking other parts of the country to metropolitan areas instead of increasing the capacity of busy lines: In other countries; the primary agenda was to optimize existing infrastructure in areas where lines and urbanization were busier. In Britain; the first high-speed rail services were at $200 \mathrm{~km} / \mathrm{h}$, and as of 1976 the diesel-powered High Speed Train has begun to operate. A more courageous attempt was recorded in 1979 with a record speed of $261 \mathrm{~km} / \mathrm{h}$ with tilting train called "Advanced Passenger Train" (APT), but this system began to be abandoned in the 1980s and this technology has only continued to be developed with Sweden's X2000 and Italy's Pendolino Operations. France's leadership was followed by three countries, Italy, Germany and Spain but approaches of these three countries are all different. Italy began to use high-speed 
trains during the war, and engineering and other difficulties have prevented it from developing. It was only in 2008 that Italy could bring the traditional Milan-Florence-Rome-Napoli Line to the High Speed Railway level. The first goal in Germany was to improve existing lines and to bring freight transport to the level of passenger transportation. This process progressed rather slowly until 1990 and the existing railway lines have remained a small number accordingly. Spain made a late entry into the operation of HSR. The main reason for this was the selection of gauge. The alignment between 'gauge diversities' within railway policies has become the most important factor. Along with that, in 1986, with the participation in the EU, 'gauge standardization' became a necessity and a considerable increase in High Speed Rail investments has begun since 2003. Indeed, in the last decade, this change has become radical, and many peripheral countries have begun to take advantage of this driving force. Belgium and the Netherlands are making expanding investments in PBKAL Services and new HSR Lines are planned and constructed in Switzerland, Portugal, Sweden and Russia at the same time.

High Speed Railways have reached a share of about $25 \%$ in passenger transport in the European Union. Turkey, South Korea, Taiwan and China in Asia; the United States in America have been implementing new HSR Services. Especially, China designated HSR Investments as the first item on the agenda. Table 2 below shows the planned high-speed railway line kilometers of the countries.

Table 2. The planned high-speed railway line kilometers of the countries [3]

\begin{tabular}{ll}
\hline Country & $\begin{array}{l}\text { Planned High Speed } \\
\text { Railway Line Length }(\mathrm{km})\end{array}$ \\
\hline China & 12.900 \\
Turkey & 3.960 \\
Spain & 7.000 \\
Italy & 600 \\
Taiwan & 345 \\
\hline
\end{tabular}

As seen in the table, Turkey, along with China and Spain, is the country where the most high-speed railway lines are planned. It should be noted here that China has a size that cannot be compared with the other countries on the table. Over the past decade, Over the past decade, China and Spain have shown the fastest development on high-speed railways, and these two countries, with France and Japan, have become the pioneer globally. In our country, there has been an unprecedented movement in the railway transport since the beginning of the 2000s and it seems that this has had a direct effect on the high-speed railway sector in recent years.

\section{High Speed Railways in Turkey (HSR)}

In our country, Ankara-Eskişehir High Speed Railway (HSR) Line was opened first and then Ankara-Konya High Speed Railway (HSR) Line and Eskişehir-Konya High Speed Railway (HSR) Line started to operate. Then the Eskişehir-İstanbul line of Ankara-İstanbul High Speed Railway Line was completed as of last year and high speed railway service between AnkaraIstanbul started to be offered. The construction of the Ankara-Yozgat-Sivas-Erzurum-Erzincan-Kars High Speed Railway (HSR) line is continuing and the construction is about to be brought to Erzincan. The construction of Ankara-Afyon-İzmir High Speed Railway (HSR) Line, Ankara-Kayseri High Speed Railway (HSR) Line, Istanbul (Halkal1) -Edirne High Speed Railway (HSR) is continuing.

These lines will be connected to the Baku-Tbilisi-Kars High Speed Railway (HSR) Line and the Bulgarian-Greek High Speed Railway (HSR) Line, whose construction work has been started and the construction works will be connected to the Anatolian site with a continuous high speed railway service to Asia, Caucasia, The Balkans and Europe.Konya-Antalya High Speed Railway (HSR), Adana-Gaziantep High Speed Railway (HSR) Line, Erzincan-Trabzon High Speed Railway (HSR) Line and Ankara-Samsun High Speed Railway (HSR) Line are other projects on the agenda and Osmaneli (Eskişehir) -Bursa-Bandırma railway lines construction is another ongoing high-speed railway line construction. Below are the lengths and travel times of the planned high-speed railway lines available in Turkey. The table clearly shows that in our country a serious high-speed railway enterprise is operated by the government (Ministry of Transport, Maritime Affairs and Communications) [4]. 
Table 3. Characteristics of Existing, Under Construction and Planned High Speed Railway Lines in Turkey [4]

\begin{tabular}{lll}
\hline Line & Distance $(\mathrm{km})$ & Travel Time \\
\hline Ankara-İstanbul & $533 \mathrm{kms}$ & 3 hours \\
Ankara-Eskişehir & $245 \mathrm{~km}$ & 1 hour 5 minutes \\
Ankara-Konya & $212 \mathrm{~km}$ & 1 hour 15 minutes \\
İstanbul-Konya & $641 \mathrm{~km}$ & 3 hours 30 minutes \\
Eskişehir-Konya & $360 \mathrm{~km}$ & 1 hour 26 minutes \\
Ankara-Sivas & $466 \mathrm{~km}$ & 3 hours \\
Ankara-İzmir & $624 \mathrm{~km}$ & 3 hours 20 minutes \\
Ankara-Afyon & $281 \mathrm{~km}$ & 1 hour 20 minutes \\
Bandırma-Bursa-Osmaneli & $190 \mathrm{~km}$ & 1 hour \\
Ankara-Kayseri & $350 \mathrm{~km}$ & 2 hours \\
Halkal1-Bulgaristan & $230 \mathrm{~km}$ & 1 hour \\
\hline
\end{tabular}

\section{High Speed Railways in the World (HSR)}

Shinkansen (Japan) constitutes more than half of the $3300 \mathrm{~km}$ high-speed railway line established worldwide in 1964-1983 period. In the same period, Britain is in the second place with a share of $28 \%$, and the development of these lines is on new lines rather than new trains. In the period of 1984-2009, a more accelerated development is observed and a high-speed railway investment of $8700 \mathrm{~km}$ was realized. In the same period, more than $4750 \mathrm{~km}$ of this total has been made during the last six years. This distance is shared by several countries, with the leader of this period being Spain with a share of $18 \%$.

France has a share of $17 \%$, Germany $15 \%$ and China 14\%. China completed these investments only in 2008-2009. In Asia in the 1960s, Japan took the lead in this regard and began to push Europe in terms of technology. By the autumn of 2009, Asia reached $35 \%$ of total lines. By the completion of the lines under construction, this ratio will reach up to 57\%, and China's HSR share in it will not be less than $41 \%$. As of the Fall of 2009, European High Speed Railways reached a total of $7100 \mathrm{~km}$, corresponding to less than $4 \%$ of Europe's total railway lines. This share of the HSR's total railways is not enough to give a definite ruling on its effectivity. In Britain, which has a relatively low density rail network, we need to evaluate differently the long distance and partly faster railway services, and suburban railway lines from the wartime period, which have lower speeds at short distances [4].

An 'automobile-focused' transportation system along with the 1980s was not sustainable due to 'air pollution, traffic congestion and high oil prices'. Congestion pricing and high road taxes have brought renewal in transport policies. The aim was to limit the use of automobiles. As a result of the economic downturn in the 1980s, the railroads again became 'environmentally friendly, energy-saving' systems, and in some countries they have come back socially and economically. This is called 'railway renaissance'.

\section{Advantages of High Speed Railways (HSR)}

Historically, high-speed railways emerged as the answer to three essential needs. The first of these was the need to surpass limited capacities of conventional lines and they have been effectively resolved with various new investments and HSR. This is precisely the reason for the emergence of Tokaido Shinkansen and TGV (French HST) Sud-Est (South-East).

Secondly, high-speed railways realized 'high speed' on much better terms than conventional lines could not achieve with high costs and shorter distances with low technology. It is possible to find this in German High Speed Railways. Thirdly, high-speed railways propose a constantly evolving accessibility to the most remote areas. The most notable examples of this are the Sanyo Shinkansen Line between Osaka and Fukuoka and the first Spanish AVE (HSR) Line route.

Table 4. Construction Costs of High Speed Railways (million USD per km) [5]

\begin{tabular}{ll}
\hline Country & Cost (million USD per km) \\
\hline France and Spain & 10 \\
Italy & 25 \\
Britain & 74 \\
South Korea & 37 \\
\hline
\end{tabular}


Table 4 shows that in South Korea, which has made some progress on high-speed railways, the line construction costs are at an average level. On the other hand, it would be more appropriate to evaluate the European Union (EU) countries in two different groups. France and Germany made great strides in high-speed railways in Europe for the first time, and in the following years Germany's pace of high-speed railway investment and development stagnated. However, especially in the last ten years, Spain has made a big leap in the high-speed railways in Europe and has become a world leader in this sector with France, Japan and China. Therefore, it is useful to classify France and Spain as advanced countries of the sector and distinguish them from the other two European countries. At the same time, it can be said that the investment costs per kilometer of the two countries as neighbors are considerably reasonable compared to other countries. It is significant that the cost per kilometer in Britain is much higher.

Urbanization is the most important phenomenon of the twentieth century. With the integration of economies into one another, globalization brought the urbanization phenomenon from the locality to the world scale. Metropolitan systems have begun to be used as new concepts as well as urbanization and urban systems.

Table 5. Average Annual Airway Traffic in the European Union (EU) [6]

\begin{tabular}{llll}
\hline Country & Route & $\begin{array}{l}\text { Air Traffic } \\
(\text { million })\end{array}$ & Passengers \\
\hline Germany & Frankfurt-Berlin & 1.6 \\
\multirow{3}{*}{ Spain } & Frankfurt-Munich & 1.5 \\
& Madrid-Barcelona & 4.0 \\
France & Barcelona- Majorca & 1.6 \\
& Paris-Nice & 3.0 \\
Great Britain & Paris-Toulouse & 2.9 \\
& London- Glasgow & 2.7 \\
Italy & London- Edinburg & 2.6 \\
\hline
\end{tabular}

At this point, technological developments connected with economic progress will determine the direction of innovation and sectoral formation in transportation. In this sense, competition between airlines and high-speed railways for medium-distance travels will accelerate further in the coming years. Table 5 above shows annual average air traffic in major cities across Europe during the year 2000. As can be seen in the table, there is significant airline passenger traffic in Europe's centers such as Rome, Paris, London, Madrid, Barcelona and Frankfurt. At this point, increasing investments in 'railway and high-speed rail', which the European Union emphasizes on sustainability axis in its related works, especially the White Paper and the TINA Report, point to another dimension of competition between the two types of transportation.

\section{Conclusion}

The railways changed the perceptions of 'distance, cultural extension and travel possibilities'. With the railways, 'standard time intervals' perception occurred and there were serious changes in lifestyle. In this context, railway stations have begun to be put forward as 'one of the symbols of modern life'. However, the discovery of automobiles in 20th century has had a major impact on the railways. Development of automobiles reduced the demand for railways significantly. Various advantages of automobiles compared to the trains were revealed. Automobiles were open to many different designs and competitive pricing. Moreover, in the 1960s, oil prices were so low that the automobiles were well positioned to be the vehicle for 'rapid economic development'. As a result, the use of automobiles has grown rapidly and has spread all over the world as a phenomenon.

All developments in transportation are natural. These developments are not limited to the technological progresses that we indicate here alone, nor to the technological progresses alone. In the economic analysis of transportation, it appears that serious progress has been made in recent years. Regarding these;

- Developments related to the application of e-economy to transportation

- Developed asset management to ensure that a more rigorous assessment / cost analysis of transport assets can be made are the developments that should be particularly stated here.

Turkey has to follow up the developments in the world economy and as a consequence, in the transport system with a new approach. Any delay in this matter will increase in amount. Today, topics such as communication-information technologies are evaluated within the context of transportation, as well as directly with the concept of transportation. Therefore, all these statements may be possible to be gathered in an integrated viewpoint. 


\section{References}

1. Candemir, Y., 'Innovations in Globalization, Technological Development and Transportation: World and Turkey', Research Gate, 2005.

2. Kızıltaş, M. Ç., 'High Speed Railway Analysis', Transportation World, 2016.

3. Kızıltaş, M. Ç., 'Global Developments in Railway Systems and Istanbul', Transportation World, 2016.

4. Ministry of transport, maritime affairs and communications (UDHB), 'Turkish State Railways', 2008.

5. Kızıltaş, M. Ç., 'European Union and Transportation Policies', Transportation World, 2015.

6. Campos, J., 'Some Stylized Facts About High Speed Rail Around The World: An Empirical Approach', 4th Annual Conference on Railroad Industry Structure, Competition and Investment Universidad Carlos III de Madrid, 2006. 